\title{
WOMEN ENTREPRENEURS AND REGIONAL DEVELOPMENT IN RURAL
}

\section{SIVAKASI}

\section{DR. K. SUBRAMANIAN}

Assistant Professor of Economics, Saraswathi Narayanan College, Madurai, Tamil Nadu, India

\begin{abstract}
Women constitute almost half of the total population of the world, but their representation in gainful employment is comparatively low. But today there is a greater awakening among women. Given the opportunity, she has proved herself in all fields and has made a significant impact on all segments of the economy. Thus to ensure women empowerment the government of India has implemented various programmes for the development of women entrepreneurship. The study uses both primary and secondary data. The primary data were collected by the researcher through interview method using a well-structured interview schedule. The secondary data were extracted from $G$ returns and statistical handbooks of Virudhunagar district. Percentile analysis has been done to study the socio-economic characteristics of women entrepreneurs engaged in tailoring, beauty parlour and food processing units. Regression analysis has been made to examine the factors determining the entrepreneurial ability measured in terms of profit rate and credit rate.

KEYWORDS: Industrialization, Women Entrepreneurship \& Economic Development
\end{abstract}

Received: Jun 13, 2021; Accepted: Jul 03, 2021; Published: Jul 15, 2021; Paper Id.: IJECRDEC20211

\section{INTRODUCTION}

Industrialization is one of the most important means of improving the economic development of a country. Entrepreneurship is always essential for economic development. In recent years, the role of entrepreneurs in the process of industrialization and economic development has fully been recognized.

There is a direct correlation between the level of economic development and the level of entrepreneurship. In common parlance, a person who is responsible for setting up a business is an entrepreneur. The writers of the $17^{\text {th }}$ and $18^{\text {th }}$ centuries hold the view that the essential characteristic of an entrepreneur is to take risks and create innovation. In 1959, Joseph Schumpter in the book "Theory of Economic Development" points out that an entrepreneur is basically an innovator who carries out new combinations to initiate and accelerate the process of economic development. Peter Drucker defines an entrepreneur as "One who always searches for changes, responds to it and exploits it as an opportunity".

David McCelland has rightly remarked "what accounts for the rise in civilization is not the external resources such as markets, minerals or factors most often among businessmen". Entrepreneurship is a composite skill. It is the resultant of a mix of many qualities and traits. These qualities are both tangible and intangible. In short, entrepreneurship is the propensity of the mind to take a calculated risk with confidence to achieve a predetermined business objective.

\section{Statement of the Problem}

Women constitute almost half of the total population of the world, but their representation in gainful employment is 
comparatively low. According to an I.L.O. report, "Women constitute 50 per cent of the world's population but own less than one per cent of the world's property. All because of an accident of birth". For centuries they have been victims of social prejudices and discrimination. Women are generally presumed to be weak, passive and dependent. They are taught to be dependent upon others, to limit their ambitions and to avoid exposure and risk. Such a role prescription and orientation had prevented her from being self-confident, innovative, motivated and risk taking, which is essential for an entrepreneurial career. As a result, they could not perform well in entrepreneurship as their career.

But today there is a greater awaiting among women given the opportunity she has proved herself in all fields and has made a significant impact on all segments of the economy. Thus to ensure women empowerment the government of India has implemented various programmes for the development of women entrepreneurship. Women, however, account for only 4.5 per cent of the total self-employed persons of India in this context, an attempt has been made to study entrepreneurs engaged in tailoring, beauty parlor and food processing units.

\section{OBJECTIVES OF THE STUDY}

The following are the objectives of the study:

- To study the socio-economy characteristics of women entrepreneurs engaged in tailoring, beauty parlor and food processing units.

- To measure entrepreneurial behavior index and study the relationship between socio-economic characteristics of women entrepreneurs and behavioral index.

- To measure entrepreneurial ability and the factors determining it.

\section{REVIEW OF LITERATURE}

Cole defines entrepreneurship as a purposeful activity of making profit. Schumpeter says that entrepreneur is an innovator. J.B. Say points out that entrepreneurship is an effort to combine the necessary factors into protective organism. Ricardo defines entrepreneurship as a motive of an individual to accumulate capital and achieve eco development.

The following table gives various definitions of the term entrepreneur as conceptualized by social scientists.

Table 1

\begin{tabular}{|c|l|l|}
\hline SI. No. & Social Scientist & \multicolumn{1}{c|}{ Definition of Entrepreneurs } \\
\hline 1 & Cantillon & Risk taker and Dealer \\
\hline 2 & Schumpeter & Innovator \\
\hline 3 & Say J B & An Economic Agent \\
\hline 4 & Peter Drucker & Innovator \\
\hline 5 & Arthur H. Cole & Decision Maker \\
\hline 6 & Karl Marks & Social Parasite \\
\hline 7 & Knight & Uncertainity-Bearer \\
\hline 8 & Adam Smith & Capitalist \\
\hline 9 & Hagger E.E. & Economic Man \\
\hline 10 & Frank Young & Change Agent \\
\hline 11 & Quesnay & Rich Farmer \\
\hline 12 & Ricardo & Capitalist \\
\hline 13 & Mill J.S. & Person with Extraordinary skill \\
\hline 14 & Walker & Organizer and coordinator \\
\hline 15 & Tinbergen & Organizer \\
\hline 16 & Kenyes & Decision maker \\
\hline 17 & Baunol & Leader \\
\hline 18 & David McClelland & Moderate Risk Taker and innovator \\
\hline & \multicolumn{2}{|l}{} \\
\hline
\end{tabular}


Jeyakumar M and Subramanian K (2021) Economic theory and various research articles point out that entrepreneurship development is more significant in commerce and industry than in agriculture. The reason is that agricultural entrepreneurship is constrained by tradition and customs. Under this situation, the green revolution programme was an experiment in India to transform traditional agriculture into a model one. The government of India implemented various programmes including the promotion of extension and farm management services. The study makes use of primary data collected through the well-structured interview schedule. The data were collected from the farmers of Vadapatti village during the months of February and March, 2021. The researcher has chosen 30 farmers based on simple random method. Data were analysed using percentile method. A linear regression equation was fitted using OLS method to study the factors determining the entrepreneurial behaviour of the sample farmers.

Mitchell B.C. (2004) studied the motivating factors for female entrepreneurs in South Africa. It was found in the analysis that the need for independence, material incentives and the need to escape a negative situation were the most important motivational factors.

Pramod Shetty (2004) made an attempt to study the attitude towards entrepreneurship in organization. A sample of 200 respondents was taken and subjected to a cluster analysis to extract the attitudes of entrepreneurs towards entrepreneurship. It was found in the study that entrepreneurs differed from intrapreneurs in terms of opportunism.

Jeyakumar. M (1995) analyzed entrepreneurial performance in terms of indicators namely profit rate, credit rate, output rate and reinvestment rate. He examined these indicators in terms of socio-economic characteristics of entrepreneurs. He used both primary and secondary data. Primary data were collected from 209 entrepreneurs. It was found that 136 entrepreneurs were successful and success rate high in engineering enterprises. In metal entrepreneurs used institutional credits effectively to emerge successfully. In chemical and chemical-based industry technically qualified entrepreneurs were highly successful. In the engineering industry, entrepreneurs who came from business families were highly successful.

Subbi Reddi and Shoba Reddi (1985) analyzed the factors responsible for entrepreneurial success. Technical education, investment exceeding Rs. 10 Lakhs and previous experience were found to be the major factors of success in entrepreneurial business.

\section{Research Methodology and Database}

The study uses both primary and secondary data. The primary data were collected by the researcher through interview method using a well structured interview schedule. The secondary data were extracted from G returns and statistical handbooks of Virudhunagar district.

\section{Period of Study}

The researcher collected primary data from 90 women entrepreneurs engaged in tailoring, beauty parlour and food processing units. The information was gathered from them during the months of March - April 2021. The primary data relating to their age, family background, education, marital status, return on capital, rate of payment of credit they have taken from various sources and so on were collected.

\section{Sample Design}

A sample of 30 women entrepreneurs from each of the entrepreneur activities has been on convenience sampling 
technique. As the list of unregistered small scale units is not available with District Industries Centre (DIC), the researcher has followed this method of non-probability sampling technique in selecting the respondents.

\section{Framework of Analysis}

Percentile analysis has been made to analyze the characteristics of women entrepreneurs engaged in Tailoring, Beauty Parlour and Food Processing Units. The regression analysis has been done to study the factors determining the entrepreneurial ability index.

The form of the regression line fitted is given below,

$$
\begin{aligned}
& E A I=a_{0}+a_{1} x_{1}+a_{2} X_{2}+\ldots . .+a_{7} X_{7} \\
& X 1=\text { Age of the entrepreneur } \\
& X 2=\text { Education of the Women entrepreneur } \\
& X 3=\text { Marital Status } \\
& X 4=\text { Previous Experience } \\
& X 5=\text { Business Background } \\
& X 6=\text { Employment of Workers (in units) } \\
& X 7=\text { Training }
\end{aligned}
$$

\section{SUMMARY OF FINDINGS}

The following are the main findings of the study:

- Nearly 23 per cent of those engaged in tailoring are in the age group of less than 30 years. There are no women entrepreneurs engaged in beauty parlour service in the age of above 40 years. Only 23 per cent of those who are engaged in food processing are in the age group of above 40 years.

- Nearly 50 per cent of the women entrepreneurs engaged in tailoring are technically qualified. Only 33 per cent of those engaged in Beauty Parlour have studied up to Plus Two. Nearly 43 per cent of the women entrepreneurs engaged in food processing are graduates.

- Nearly 57 per cent of the women entrepreneurs engaged in tailoring are unmarried. Only 34 per cent of those engaged in Beauty Parlour are married. Nearly 70 per cent of the women entrepreneurs engaged in Food Processing are married.

- Exactly 40 per cent of the women entrepreneurs engaged in tailoring have a previous experience of 1-2 years. Nearly 24 per cent of those engaged in Beauty Parlour have no previous experience. Nearly 33 per cent of the women entrepreneurs engaged in food processing have previous experience of less than one year.

- Nearly 50 per cent of those who do beauty parlour services do not hail from business families. Nearly 70 per cent of those engaged in food processing hail from business families. Nearly 63 per cent of sample women entrepreneurs doing tailoring services have a business background. 
- Nearly 57 per cent of the women entrepreneurs engaged in tailoring provide employment for more than five persons each. Nearly 50 per cent of the women entrepreneurs engaged in Beauty Parlour provide employment for less than three persons. Only 50 per cent of the women entrepreneurs engaged in food processing provide employment 3-5 persons.

- Nearly 57 per cent of the women entrepreneurs engaged in tailoring service have got training for a period of less than three months. Exactly 60 per cent of those who do beauty parlour service are trained for a period of 3-5 months. As many as six out of 30 women entrepreneurs engaged in food processing units are not at all trained.

- The inference is that the inclination of the women entrepreneurs in the study area towards the implementation of modern designs in tailoring has been relatively low.

- It is noticed that five out of 11 entrepreneurs showing higher level of entrepreneurial behavior are in the age group of less than 35 years.

- The results indicate that 10 out of 11 women entrepreneurs showing higher entrepreneurial behavior are either graduates or technically qualified in tailoring service.

- It has been found that nine out of 11 entrepreneurs who secured the behavioural score of more 50 per cent are married. That is, married women entrepreneurs have higher level of entrepreneurial behavior in tailoring service.

- It has been found that previously experience women entrepreneurs engaged in tailoring service show higher level of entrepreneurial behavior.

- Further, seven out of 11 who have become entrepreneurs without business background exhibit lower level of entrepreneurial behavior in tailoring service.

- Two out of four women entrepreneurs employing less than three persons have entrepreneurial behavior index of less than 50 per cent. It is found that those who employ more than three persons in their units show higher level of entrepreneurial behavior in tailoring service.

- It is found that those who employ more than three persons in their units show higher level of entrepreneurial behavior in tailoring service.

- Exactly eleven women entrepreneurs exhibiting higher level of entrepreneurial behavior are trained in tailoring service.

- The entrepreneurial behavior score was low for many women entrepreneurs engaged in beauty parlour service. The inference is that the indication of the women entrepreneurs in the study area towards implementation of innovative service in Beauty Parlour has been relatively low.

- The score obtained for the entrepreneurial behavior for most of the women entrepreneurs engaged in food processing has been low. The inference is that the inclination of the women entrepreneurs in the study area towards the implementation of differentiated products in food processing has been relatively low.

- The trained women entrepreneurs who are engaged in tailoring service could show higher ability. Further, previous experience of the women entrepreneur also determines the ability positively in tailoring service. Those 
women entrepreneurs who are aged and hail from business families are able to show higher ability in the food processing business. The women entrepreneurs who are trained and previously experienced are showing higher entrepreneurial ability in beauty parlour service.

\section{SUGGESTIONS}

Based on the findings of the study the following suggestions are made to improve the development of women entrepreneurship in the study area:

- Training is the main factor determining the performance of women entrepreneurs in tailoring and beauty parlour service. Hence effective training strategy may be evolved to train women entrepreneurs in these areas.

- The entrepreneurial behavior index is low in most all cases. This is because women entrepreneurs are reluctant in gathering information relating to their business. Thus they must be motivated to elicit the information required for their business. This will help them to show higher entrepreneurial ability and face stiff competition everywhere.

\section{REFERENCES}

1. Jeyakumar M and Subramanian K (2021), Agripreneurship Among Farmers in Rural Sivakasi, International Journal of Social Science \& Management Studies, Vol. - 7, No. - 4, pp. 41-43

2. Muhammad Bello Muhammad, Rahimah Abdul Aziz \& Vivien W.C. Yew, "Socio-Economic Effects of Industrialization in the Society", International Journal of Environment, Ecology, Family and Urban Studies (IJEEFUS), Vol. 8, Issue 4, pp, 23-30

3. Mitchell, B.C. (2004), Motives of Entrepreneurs: A Case Study of South Africa", The Journal of Entrepreneurship, Vol.13, No.2, P.180.

4. Desai B \& Desai H, "Assesment of Water Quality Index for Ground Water of Industrialized Area of Surat City, Gujarat, India", International Journal of Environment, Ecology, Family and Urban Studies (IJEEFUS), Vol. 6, Issue 1,pp, 135-150

5. Pramod Shetty (2004), "Attitude Towards Entrepreneurship in Organisations", The Journal of Entrepreneurship, Vol. 13, No. 1, pp. 53-60.

6. Mohammad Zakir Hossain Khan, "A Case Study on Occupational Health and Safety of Footwear Manufacturing Industry", IASET: Journal of Business and General Management (IASET: JBGM), Vol. 2, Issue 1, pp; 1-6

7. Rachana, Chattopadhyay and Anjali Ghosh, (2002), "Predicting entrepreneurial success: A Socio-psychological study", The Journal of Entrepreneurship, Vol. II, No.1, pp.23-30.

8. Sukhpal Singh (2001), "Employment, Efficiency and Entrepreneurship in Small Industry: A Study of the Banking Industry in Punjab, India", The Journal of Entrepreneurship. Vol. 10, No.1, pp. 72-87.

9. Narender Singh, "Utilization of Plastic Waste to Improve the Properties of Aggregates Using Dry Process", International Journal of Civil Engineering (IJCE),Vol. 4, Issue 5,pp, 17-24

10. Jeyakumar, M. (1995), An Economic Study of Entrepreneurial performance in Small Scale Industries in Madurai District, Ph.D. Thesis submitted to Madurai Kamaraj University, Madurai.

11. Kamla Singh (1992), Women Entrepreneurs, “Ashish Publishing House, New Delhi, pp.63-65.

12. Gupta M.C. (1987), Entrepreneurship in Small Scale Industry”, Anmol Publications, New Delhi.

13. Subbi Reddi and Shoba Reddi, (1985), Successful Entrepreneurship - A Study productivity," Vol. XXVI, No.1, pp.21-31. 